\title{
RESTRUCTURING OF MANUFACTURE UNDER GLOBAL FINANCIAL AND ECONOMIC CRISIS: THE CASE OF ESTONIA
}

It was not possible for Estonia only by raising the technological level of enterprises and increasing so-called technical productivity to catch up in terms of productivity with the developed industrial countries. The structure of Estonian manufacture was out-of-date and required cardinal and fast changes toward greater value added.

Every time a crisis hits, it brings about new breakthroughs in science and technology; promotes fundamental changes that take place in a relatively short period of time; gives birth to new industries; forms new growth points in the economy. The crisis has had a far-reaching impact on the world economy and has brought challenges and opportunities to all countries and all fields. In addition to big difficulties, the crisis provided for Estonian manufacture also an exceptionally good chance for change and development.

The crisis had a purifying and disciplining effect, enabled to eliminate from the manufacture wrong investments and inefficient enterprises. Assets were redistributed from passive economic agents to active ones and in favour of those who had capital for growth financing. After the crisis the structure of Estonian manufacturing is more effective than before: 1) technological level higher; 2) organization of work more perfect; 3 ) value added and productivity higher; 4) position of value chain better; 5) maybe also the value chain itself new and better.

But there are fewer jobs in the new structure of manufacturing than before the crisis. Economic, social, regional etc. stratification has increased. The influence of crisis is not over yet and there is still a risk of some setback in future. There may also arise new problems and old problems may grow sharper.

Key words: crisis; manufacture; restructuring; stratification

\section{Introduction}

Manufacturing is the use of machines, tools and labor to produce goods for use or sale. The term may refer to a range of human activity, from handicraft to

Kaarel Kilvits, Professor at the School of Economics and Business Administration, Tallinn University of Technology, Estonia, e-mail: kaarel.kilvits@tseba.ttu.ee 
high tech, but is most commonly applied to industrial production, in which raw materials are transformed into finished goods on a large scale.

A challenge is a general term referring to things that are imbued with a sense of difficulty and victory - a call to engage in contest, fight, or competition. Opportunity is a good chance for advancement or progress.

The current (or by now already past) global financial and economic crisis has had a far-reaching impact on the world economy and it has brought challenges and opportunities to all countries and for all fields. Every time a major crisis hits, it brings about new breakthroughs in science and technology; promotes fundamental changes that take place in a relatively short period of time; gives birth to new industries, and forms new growth points in the economy.

This paper seeks to cover contemporary challenges and opportunities of Estonian manufacture after the global financial and economic crisis. The general situation and tendencies in the world economy influencing restructuring of manufacture in a small open economy of the European Union member state are discussed. The main goal of this paper is to summarize the objectives and experiences of knowledge applied by different agents and to study alternatives and opportunities in this process. Specific focus of this paper will be on main tendencies in the world manufacturing and the peculiar situation of a very small, open and integrated manufacture.

\section{The Structure of Estonian manufacture before hlobal financial and economic crisis}

Most fundamental changes in Estonian manufacturing took place in 19921999 when manufacturing adapted to the new political and economic conditions. After the drastic structural changes in the early 1990s (in connection with regaining independence and the transition-reversion-return-comeback from planned economy to market economy) and the Asian-Russian crisis provoked slowing down of the growth in 1998-1999, the Estonian manufacturing enjoyed for eight years a relatively stable and fast growth. It stabilized around $10 \%$ in 2001-2006.

Since 2000, the structure of Estonian manufacturing has become more stable. Structural changes in this period were quite slow, insignificant and painless. Entrepreneurs grew used to it and believed that it's the way it has to be and will be. The predominant opinion in this period was that Estonia had almost accomplished its great ambitions: 1) re-establishment of independence August 20, 1991; 2) withdrawal of Russian troops - August 31, 1994; 3) NATO membership - March 29, 2004; 4) European Union membership - May 1, 2004; 5) Schengen membership - December 21, 2007. Many were of the opinion that there was only one big aim left to accomplish for Estonia - join the Economic 
and Monetary Union of the European Union (EMU). Then Estonia would be the most integrated country in Northern Europe - only Estonia would be involved in four integration programs of Western democracies (EMU; Schengen zone; EU; NATO) in this region.

But relatively stable development and missing fundamental structural changes were dangerous for Estonian manufacturing. Employment in Estonia was unfortunately concentrated into sectors of manufacture where it was not possible to significantly increase productivity and hence also value added. Enterprises operated to a small extent in those economic sectors where productivity increase was more feasible or in less profitable part of value chains. Such conditions set limits to the further growth capacity of the Estonian manufacturing.

A research ordered by the Estonian Development Fund from Tartu University (Arengufond, 2008) calculated that if all branches of Estonian manufacturing achieved the productivity that is in the respective branch of manufacturing in the most advanced countries in European Union while the distribution of Estonian labor between the branches of manufacturing remains the same as now, then productivity in Estonia would attain only $56 \%$ of the Irish, $78 \%$ of the German, $80 \%$ of the Finnish and $90 \%$ of the Danish level. Hence, it was not possible for Estonia only by raising the technological level of enterprises and increasing so-called technical productivity to catch up in terms of productivity with the developed industrial countries. The structure of Estonian manufacture was outof-date and required cardinal and fast changes toward greater value added.

\section{Challenges and opportunities provided by global financial and economic crisis for Estonian manufacture}

In 2000-2002, labor productivity in Estonian manufacturing increased faster than production volume. In 2003-2007, when the increase in production stabilized, the volume of output and productivity growth almost equalized. During that period Estonian manufacturing enterprises did not contribute to productivity growth and where production demand increased also additional staff was hired. The increase in labor costs augmented enterprises' costs, which in turn led to price increase of products and reduced the competitiveness of Estonian manufacturing enterprises.

Notwithstanding all sorts of financial and economic regulations cycles are inevitable in a market economy. The year 2007 already showed the first signs of slowdown in production growth. The beginning of decline cycle appeared in manufacturing at the beginning of 2008. Already then it was clear that both Estonian economy and global economic environment had significantly changed in recent years. Labor shortage had been replaced by unemployment, prices for many product inputs had increased and credit facilities more difficult to 
obtain. An inner structural crisis had developed in Estonian economy and real economic growth slowed down. A global financial crisis broke out in September 2008, which soon grew into a global economic crisis.

Developments in the world were still only the context for specific developments in the Estonian manufacturing - global financial and economic crisis had very different overall effects on different countries. The world financial crisis that began in 2008 affected countries in different ways, depending on their forms of international integration (Myant and Drahokoupil, 2011; Wade, 2008; 2009; Friedman, 2009; Stiglitz, 2009). Global financial and economic crisis was very badly timed for Estonia. In the years of rapid economic growth, when domestic demand was relatively high companies were not forced to contribute to productivity growth. An inner structural crisis had already developed in the Estonian economy. The Estonian economy had already grown weak and vulnerable to external shocks. Sharp deterioration of global conditions meant for Estonia amplification and piling up of two big factors (inner and outer), and contraction of the economy was inevitable. Real economic growth in Estonia slowed down very sharply.

The Estonian manufacturing had reached the stage of faster, more radical and painful structural changes again. It was realized that further development in Estonia will be to a very large extent determined just by external factors developments in the world (especially in EU) and in the economic environment. These determine in the main challenges, opportunities and economic playground for Estonia.

The Estonian economy is very small and very open. It participates in international trade, but is small enough compared to its trading partners, so its policies do not alter world prices, interest rates, or incomes. The Estonian economy is a typical price taker. In 2008, Estonia's foreign trade (export 132.4 billion kroons + imports 170.0 billion kroons $=302.4$ billion kroons) to GDP (251.5 billion kroons) ratio was 1.20, one of the highest in the world (Statistics Estonia, 2011; Eurostat, 2011). Due to the very small domestic market exports, i.e. successful sales in the world market are the main driving force of the economy and the main source of economic growth. The export share of manufacturing output remained just below half of the production until 2000. In 2000 the magical 50\% threshold was exceeded.

As the Estonian economy depends on exports, it, manufacturing included, is extremely sensitive (much more sensitive than large countries with more closed economies) to all influences of the global economic environment. In 2008, compared to 2007, production decreased 4.5\%. 2009 turned out an even amore difficult year for Estonian manufacturing. The decline in manufacturing grew into the biggest financial and economic crisis during the last decades. In 2009, compared to 2008, Estonian manufacturing production decreased as many as $28 \%$. This was caused by inadequate demand on both domestic and foreign markets. 
But in addition to big difficulties, the global financial and economic crisis provided for Estonian manufacture also an exceptionally good chance for change and development. The situation changed considerably and it was not possible to go on as before. The global financial and economic crisis had a purifying and disciplining effect, enabled to eliminate from the manufacturing wrong investments and inefficient enterprises, lowered the proportion of domestic market focused branches. Assets were redistributed from passive economic agents to active ones and in favor of those who had capital for growth financing. During boom years, the economy was mainly simply expanding, but during the decline, new ideas and more effective ways were searched for. Now it was possible to realize changes what was impossible to do during stable and fast growth.

During the global financial and economic crisis, several industries with long historical traditions disappeared in Estonia. Also several relatively new enterprises set up by foreign capital in the 1990s, which were primarily focused on cost advantage (low taxes, cheap labor, electricity, water etc, partly also cheap resources and materials bought from Russia) and not interested in operating in Estonia for long, terminated their activity in Estonia. Many low-technology, labor-intensive and low-capital-intensive productions that came to Estonia during that period moved on to CIS or Asia.

Unlike the developed and rich industrial countries Estonia had not in the least interested in keeping its status quo, and wanted to change it quickly and essentially. The global financial and economic crisis provided for this an exceptionally good chance. All sorts of developments, international relocation of production and reallocation of economic power in the world gathered speed.

Although: 1) the global financial and economic crisis had caused an economic decline in the countries Estonia was exporting to; 2) the protectionist tendencies - also inside European Union - had grown stronger; 3) suppliers demanded advance payments; 4) the Estonian kroon being pegged to euro had grown more expensive for some currencies (Sweden, Russia, Ukraine etc.) of export countries; 5) loan raising was much more difficult than previously, etc, attempts were made by Estonian manufacturing enterprises to take maximum possible advantage during the global financial and economic crisis. The more that there were positive developments also for entrepreneurs: 1) raw material prices in the world market had fallen; 2) real estate was cheaper; 3 ) wage pressure had abated; 4) the failing enterprises disappeared from the market leaving gaps and many enterprises were looking for new cooperation partners, 5) supply chains were changing; 6) international corporations were selling local subsidiaries etc.

The state of Estonia (in the first place Enterprise Estonia, Development Fund, Tallinn Entrepreneurship Agency, various techno parks, ministerial units of innovation etc.) had tried, within the limits of competence and financial resources, to create an innovative economic environment and provide general recommendations for economic development. The recommendations of the 
state arose from a matter of fact that: 1) the wealth distribution scheme in the contemporary globalized world is contradictory; 2) success of advanced industrial economies is based on specialization in useful, high-value-added activities; 3) incomes of the participators in the world economy are most influenced by whether and how they can find a niche in a high-value-added branch and value chain. Unfortunately, the state of Estonia was not able (competent) to say what exactly should be done and can be done. Entrepreneurs themselves had to devise a successful business plan.

Enterprises had the following strategy options in that period: 1) lower costs revise all processes and their management (organizational innovation); 2) change their production or services - differ from others (product or service innovation); 3) increase revenue - sales outside Estonia, continuing internationalization, cooperation with partners; 4) replace labor with capital - investment, reduce labor-intensive production; 5) change the position in value chain - move toward end consumers or toward product development.

Usually Estonian manufacturing enterprises in this period acted in the following way:

- Estonian manufacturing enterprises tried to shift from branches and activities where it was difficult significantly to increase productivity and value added, to more profitable and promising ones.

- Estonian manufacturing enterprises started to increasingly more operate in international networks and value chains. They located procurement, production, distribution, marketing, sales and services in different countries across the world. They performed every operation where the price-quality ratio was the best. Transnational relocation of production - mainly through foreign direct investment and subcontracting - was growing at an increasingly faster rate. Estonian manufacturing enterprises tried to find their opportunities in the "declining" market, profitable niche.

- Estonian manufacturing enterprises made attempts, by developing production, technology and sales, to climb up in the value chain, increase value added and profitability. Producers or service providers used mainly three possibilities to raise the value: 1) turn into a product developer; 2 ) turn into a brand holder; 3 ) move up in the value chain to higher value added products/services.

- For increasing productivity the target was set to high-technology production, which, as a rule, guarantees higher productivity and greater value added. But owners and executive managers of Estonian manufacturing enterprises understood that high-technology branches shouldn't be identified with high-technology production. All branches today contain segments of high-technology production and products, effective marketing channels, well-known brands etc. In the global mar- 
ket a brand owner in low-technology branch earns as a rule more than most of the subcontractors in high technology branches. Value added in electronics industry as a whole is definitely higher than in textile industry. But on the other hand, there are many low-productivity enterprises and entire branches in electronics industry (primitive subcontracting, assembly operations etc.). And, for example, in textile industry there are old, famous enterprises producing billiard and game table fabrics which own a well-known brand and earn enviably high profits, factories producing various specific products (cloths for firemen and racers, bulletproof fabric etc.).

- Leading manufacturing enterprises in Estonia tried to implement a strategy of big Western corporations. They dedicated themselves only to product development, logistics and marketing. They tried to administer trademarks, product portfolios and value chains. Production was organized in some "cheap" country. Such enterprises tried to work as "producer without a factory".

- If it was not (yet) possible to be successful with end products, attempts were made to be competitive at least in the subcontracting market. Estonian manufacturing enterprises tried to shift from single procurement contracts to long-term contracts, become standing suppliers, participate in $\mathrm{R} \& \mathrm{D}$ activity, achieve high technological competence, being aware of the whole production cycle. Enterprises tried to orient to such hightechnology subcontracting that the customers were not capable of doing themselves. For that they needed to own something that customers didn't - know-how, specialists, equipment or something else. These were the subcontractors customers concluded long-term contracts with and assisted in introducing standards, management systems etc. For such subcontractors customers paid well and such business partners were respected. There was much less sense to orient to such subcontracts which could be done cheaper than by the customer (a better price to quality ratio), for production for which the contracting entity had no sufficient production capacities or what was ordered outside to diversify risks (so as not to create production capacities which, when the conjuncture grows worse, will remain under-utilized).

- Estonian manufacturing enterprises tried continuously to use their proximity to the West-European market, their ability to produce small quantities, as well as operative and flexible production. In China and India one can get a subcontract at a better price-quality ratio than Estonia. Fortunately for Estonia, these countries are far away from large Western firms. Those who order subcontracts prefer to avoid large time differences, long air travel; they have problems with an inadequate infrastructure, different culture and food they are not accustomed to. There- 
fore they have so far preferred Estonia. Employees of the large firms in Nordic countries and Western Europe, which are up to three hours of travel from Tallinn, prefer Estonia regardless of the worse price-quality ratio. However, time is not working in favor of Estonia. The price-quality ratio is growing more and more significant.

Estonian manufacturing had a splendid opportunity to exit from the global financial and economic crisis as a winner, and take up a more dignified position in international division of labor than before the crisis. This, however, demanded many fundamental changes.

In 2007 , Estonia was given the $163^{\text {rd }}$ place in terms of labor market flexibility in the international rating of 181 countries (Eurostat, 2011; ILO, 2011). The new Employment Contracts Act (Employment Contracts Act, 2008), which entered into force on July 1, 2009, improved the situation in the Estonian labor market. Now the labor market is more flexible and labor force can easily and rapidly move from low-productivity branches to more productive ones.

The educational system changed more flexible too. A problem for Estonia during the boom years was that the labor market gulped down people with three years of general higher education who needn't be and were not specialists. Large drop-out numbers from school threatened long-term competitiveness of Estonia. Economic decline and the related unemployment provided many with a forced opportunity to continue education and graduate. At the same time, career counseling of high-school graduates improved significantly, as well as retraining and continuing education (Estonian Ministry of Education and Research, 2011). One can hardly plan what kind of new professional skills exactly people should be taught. But the training process itself is very important. People come together, share ideas and are more alert to notice new work opportunities.

The structure of Estonian manufacturing improved slightly between 2008 and 2010. The rate of employment with labor-intensive and small value-added textile and clothing industry dropped from 19.6 to 13.8 thousand (from 14.5\% to $12.7 \%$ ), whereas in the higher value-added metal, machinery and apparatus industry only from 37.2 to 31.4 thousand (from $27.5 \%$ to $28.9 \%$ ). (Statistics Estonia, 2011).

The structure of Estonian exports also improved a little - the processing degree and value added of goods increased. Exports were differentiated (risk diversified) and largely oriented to quite stable European Union member states (Statistics Estonia, 2011), especially Finland (17\% of Estonia's total exports in 2010) and Sweden (16\%). In imports of metal, machinery and apparatus industry production of these countries the share of Estonia increased in 2010 (Eurostat, 2011). 


\section{Challenges and opportunities of Estonian manufacture after the global financial and economic crisis}

The year 2010 can be regarded as a successful year for Estonia. The economy started to recover from the crisis, the confidence of entrepreneurs and consumers improved, especially significant was the growth of export volumes (Estonian Institute of Economic Research, 2010). While in the middle of 2009, Estonia was the country with the largest decrease in manufacturing production among the EU Member States, then in the $2^{\text {nd }}$ quarter of 2010 Estonia became the country with the most rapid growth of production (Statistics Estonia, 2011).

However, the influence of global financial and economic crisis is not over yet and there is still a risk of some setbacks during further improvement of world economy: 1) support packages of many countries have restored their domestic demand, increasing demand also for Estonian exports, including subcontracting. When the main destination countries for Estonian exports (Finland, Sweden, Germany) terminate their economic revival programs, demand in these countries - particularly for subcontracting of Estonian manufacture - may decrease again and so will Estonian exports; 2) there is a risk (temptation) that under fallen labor costs (wages) Estonian manufacturing enterprises do not accomplish any fundamental changes - cheap workforce enables to produce and sell again laborintensive, but low value-added products and services. This however will lead to repeat crisis. Moving out of the crisis is the immediate challenge, but the biggest challenge is to escape the reflex to try to return the pre-crisis situation.

There may also rise new problems and old problems may grow sharper. After the crisis, the structure of Estonian manufacturing will be, without any doubt, better and more effective than before: 1) technological level higher; 2) organization of work more perfect, 3) value added and productivity higher; 4) position in value chain better; 5) maybe also the value chain itself new and better. But a problem is that there are fewer jobs in the new structure of manufacturing than before the crisis (in 2008135.0 thousand; in 2010108.4 thousand) (Statistics Estonia, 2011). Unemployment remains extremely high, and continues to be problematic.

Another problem may be also that investment-intensive new high-technology, high value-added jobs are created mainly in Estonian capital city - Tallinn. And only top specialists and skilled workers in the capital city will benefit from these, not "ordinary people" in other regions. Not all people are qualified and do not fit into high-technology production. Such structural changes may even increase economic, social, regional etc. stratification. Estonia needs also lowtechnology production for employing uneducated and not so highly skilled people. Structural unemployment in Estonia has increased. Such development is pushing further still the economic, social and regional stratification. 
Manufacturing has been, and continues to be, critical to the success of the Estonian economy. Manufacturing is covering an important share of GDP. Due to political and economic changes since Estonia became independent a number of structural changes have taken place in development of manufacturing. Compared to the beginning of 1990s, the share of manufacturing in GDP has decreased from $20 \%$ to about $16 \%$. As a result of the global financial and economic crisis, the share of manufacturing accounted only for $14 \%$ of GDP in 2009. In spite of the very big decrease in production during the crisis, also a very rapid growth of manufacturing took place starting at the beginning of 2010. Already in the $2^{\text {nd }}$ quarter of 2010, the share of manufacturing in GDP had increased to $16 \%$ again (Statistics Estonia, 2011).

Estonian economy can be successful only by being strongly export orientated. Estonia needs to „export itself out of the crisis”. Therefore Estonia needs new exporting enterprises or to expand the existing ones. Yet many Estonian people work abroad. A worker with a medium qualification can earn in Estonia's neighboring country Finland more than EUR 1400 monthly. Only few enterprises in Estonia can pay such wages. Average wage in the electronics industry, which was on top of Estonia's export growth, was only EUR 800 in 2010. It is impossible to pay more otherwise it would be more reasonable for enterprises to move away from Estonia, to Bulgaria or farther.

Estonian manufacturing needs much more activity and better coordination so as more value added producing manufacturing industries would come to Estonia or develop here for the world market. But this is not easy. Estonian manufacturing will need to adapt and transform to new realities in which continuing globalization, international competition and innovation will play a pervasive role.

Estonian manufacturing enterprises have taken the orientation to main growth domains (sustainable energy and environmental products which enable to prevent or mitigate environmental changes and energy crisis, and/or are environment friendly: health and welfare products which increase human life expectancy and quality). Attempts were made to focus on growing markets (China, India, Brazil, etc.).

Estonian workforce has been much cheaper than in developed industrial countries and so-called technical productivity not very much lower. A problem is rather the position of Estonian manufacturing enterprises in value chains and selling skills in general.

Increased supply of workforce dismissed from the real estate sector (construction) during the crisis was an opportunity for the forced development of manufacturing sector and increase in exports. Unfortunately such tendency moving towards a post-industrial society - may be only temporary.

It is not possible to catch up with the advanced industrial economies only by updating production technology and making production increasingly more cost 
effective. Also changes in the manufacturing industry structure are necessary. This means development of new growth areas and in the traditional branches moving toward activities that give higher value added.

When Estonia grows more attractive for foreign investors, and if the present trends continue, Estonia may become rather attractive to investments orientated to short-term motivation related cost-saving, which might exert Estonia a useful effect during a few years but won't be sustainable in long-term perspective.

The previous economic policy (openness, macro-economic equilibrium), creating a favorable environment, which has brought success, is clearly necessary still. But this is not enough in the new situation. We need a focused, pro-active economic policy which has a bigger role in identifying strategic branches for the state, leading and systematically developing them. This means amplification of existing strengths, testing in new growth areas and resource mobilization and trans-sectoral cooperation for that. Economic policies must grow much more forceful, focused and related to other policies (education, sciences, foreign economic policy).

Unfortunately the competitiveness of subcontracting manufacturing enterprises of Estonia is negatively affected by that the airport of Tallinn lags significantly behind the airport of Riga by number of airlines and destinations. Price-quality ratio of subcontracting in Baltic countries is more or less the same and West-European enterprises which order subcontracts from the Baltic region have therefore started to prefer Riga where they can fly from many cities without changing planes.

While previously cost and profit were the main determinants in the traditional location theory, then nowadays soft factors such as "quality of life" (housing and environment), "image" of place or "private" reasons are very important determinants. Modern living and work environment are very important for potential high-technology investors and skilled labor. Highly skilled workers/specialists, as a rule, have a well-kept and demanding family for the living conditions. They are willing to live and work only in a region where there is a good infrastructure. Or move to such place from a place that does not satisfy them. A high-quality living environment is an increasingly important location decision factor for companies which need to attract young and talented educated workers. The availability and range of high-quality affordable housing is increasingly important.

\section{Conclusions}

It was not possible for Estonia only by raising the technological level of enterprises and increasing so-called technical productivity to catch up in terms of productivity with the developed industrial countries. The structure of 
Estonian manufacture was out-of-date and required cardinal and fast changes toward greater value added.

Every time a major crisis hits, it brings about new breakthroughs in science and technology; promotes fundamental changes that take place in a relatively short period of time; gives birth to new industries, and forms new growth points in the economy. Global financial and economic crisis has had a far-reaching impact on the world economy and it has brought challenges and opportunities to all countries and for all fields.

In addition to big difficulties, the global financial and economic crisis provided for Estonian manufacture also an exceptionally good chance for change and development. The global financial and economic crisis had a purifying and disciplining effect, enabled to eliminate from the manufacture wrong investments and inefficient enterprises, lowered the proportion of domestic market focused branches. Assets were redistributed from passive economic agents to active ones and in favor of those who had capital for growth financing.

After the crisis, the structure of Estonian manufacturing is better and more effective than before: 1) technological level higher; 2) organization of work more perfect, 3) value added and productivity higher; 4) position in value chain better; 5) maybe also the value chain itself new and better.

The year 2010 can be regarded as a successful year for Estonia. The economy started to recover from the crisis, the confidence of entrepreneurs and consumers improved; especially significant was the growth of export volumes. But the influence of global financial and economic crisis is not over yet and there is still a risk of some setbacks during further improvement of world economy. There may also arise new problems and old problems may grow sharper.

There are fewer jobs in the new structure of manufacturing than before the crisis. Investment-intensive new high-technology, high value-added jobs are created mainly in Estonian capital city - Tallinn. And only top specialists and skilled workers in the capital city will benefit from these, not "ordinary people" in other regions. Not all people are qualified and do not fit into high-technology production. Such structural changes may even increase economic, social, regional etc. stratification. Estonia needs also low-technology production for employing uneducated and not so highly skilled people. Structural unemployment in Estonia has increased. Such development is pushing further still the economic, social and regional stratification.

Unfortunately the competitiveness of subcontracting manufacturing enterprises of Estonia is negatively affected by that the airport of Tallinn lags significantly behind the airport of Riga by number of airlines and destinations. The price-quality ratio of subcontracting in Baltic countries is more or less the same and West-European enterprises which order subcontracts from the Baltic region have therefore started to prefer Riga where they can fly from many cities without changing planes. 
While previously cost and profit were the main determinants in the traditional location theory, then nowadays soft factors such as "quality of life" (housing and environment), "image" of place or "private" reasons are very important determinants. Modern living and work environment are very important for potential high-technology investors and skilled labor. Highly skilled workers/specialists, as a rule, have a well-kept and demanding family for the living conditions. They are willing to live and work only in a region where there is a good infrastructure. Or move to such place from a place that does not satisfy them. A high-quality living environment is an increasingly important location decision factor for companies which need to attract young and talented educated workers. The availability and range of high-quality affordable housing is increasingly important.

Whether Estonian manufacturing is able to achieve stability in the coming years depends on economic and political decisions and surrounding economic climate. The current situation gives hope that export based on cheap production will be replaced with more qualitative final production providing higher value added. Estonian manufacturing will need to adapt and transform to new realities in which continuing globalization, international competition and innovation will play a pervasive role.

\section{Literature}

- Arengufond (Estonian Development Fund) (2008). Eesti majanduse konkurentsivõime hetkeseis ja tulevikuväljavaated (Competiveness of Estonian economy and future prospects).

- Employment Contracts Act (2008). Retrivered from http:/www.sm.ee/filead$\mathrm{min} /$ meedia/Dokumendid/ Toovaldkond/TLS_eng.pdf; 14.03.2011

- Estonian Institute of Economic Research (2010). Konjunktuur, 4(175).

- Estonian Ministry of Education and Research (2011). Retrivered 20.02.2011 from http://www.hm.ee.

- Eurostat (2011). Retrivered 20.02.2011 from http://epp.eurostat.ec.europa.eu.

- Friedman, J. (2009). A Crisis of Politics, Not Economics: Complexity, Ignorance and Policy Failure. Critical Review: A Journal of Politics and Society, 21(2), 127-183.

- ILO (2011). Retrivered 20.02.2011 from http://www.ilo.org/global/lang-en/ index.htm.

- Myant, M. and Drahokoupil, J. (2011). Transition Economies: Political Economy in Russia, Eastern Europe, and Central Asia. Wiley. John Wiley \& Sons, Inc.

- Statistics Estonia (2011). Retrivered 20.02.2011 from http://www.stat.ee. 
- Stiglitz, J. (2009). The Anatomy of Murder: Who Killed America's Economy? Critical Review: A Journal of Politics and Society, 21(2), 329-339.

- Wade, R. (2008). The First-world Debt Crisis 2007-2010 in Global Perspective. Challenge, 51(4), 23-54.

- Wade, R. (2009). From Global Imbalances to Global Reorganizations. Cambridge Journal of Economics, 33(4), 539-562. 
Prof. Kaarel Kilvits,

Fakultet za ekonomiju i poslovnu administraciju,

Tehnološki univerzitet u Talinu, Estonija

\section{RESTRUKTURIRANJE PROIZVODNJE U OKOLNOSTIMA GLOBALNE FINANSIJSKE I EKONOMSKE KRIZE: SLUČAJ ESTONIJE}

\section{S a ž e t a k}

Nije bilo moguće da Estonija samo sa podizanjem tehnološkog nivoa preduzeća i povećanjem, takozvane, tehnološke produktivnosti sustigne nivoe produktivnosti razvijenih industrijskih zemalja. Struktura estonske proizvodnje je bila zastarela i zahtevala je sveobuhvatne i brze promene ka postizanju veće vrednosti.

Svaka kriza sa sobom donosi nova otkrića u nauci i tehnologiji; promoviše fundamentalne promene koje se dešavaju u relativno kratkom periodu; donosi sa sobom razvoj novih industrija; formira nove polazne tačke razvoja u ekonomiji. Kriza je imala veliki uticaj na globalnu ekonomiju i sa sobom je donela nova iskušenja i mogućnosti svim zemljama i na svim poljima. Zajedno sa velikim iskušenjima, kriza je obezbedila estonskoj proizvodnji izuzetno dobru šansu za promene i razvoj.

Kriza je dodatno omogućila da se uvedu red i disciplina, omogućavajući da se iz proizvodnje eliminišu pogrešne investicije i neefikasna preduzeća. Aktiva je preraspoređena iz poseda pasivnih ekonomskih činilaca ka onim aktivnim i prednost je data kapitalu za finansiranje razvoja. Nakon krize, struktura estonske proizvodnje je efikasnija nego pre: 1) viši tehnološki nivo 2) bolja organizacija rada 3) dodatna vrednost i veća produktivnost 4) pozicija lanca vrednosti je bolja 5) takođe, možda je i lanac vrednosti nov i bolji

Ali, broj radnih mesta je manji u novoj proizvodnoj strukturi nego pre krize. Ekonomska, društvena, regionalna, itd... stratifikacija je uvećana. Uticaj krize je i dalje prisutan i postoji rizik za nekim budućim preprekama u razvoju, a moguća su i pojavljivanja nekih novih problema kao i dodatno zaoštravanje starih.

Ključne reči: kriza; proizvodnja; restrukturiranje; stratifikacija 
